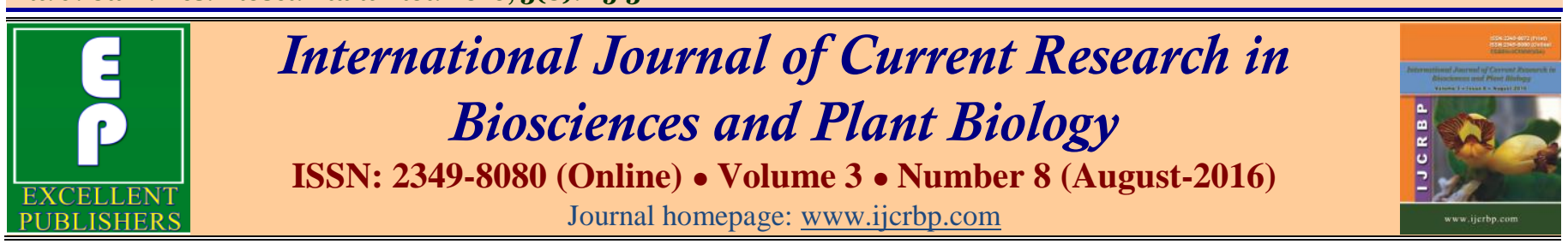

\title{
The Effects of Some Ecological and Anthropic Factors on the Survival and Bark Recovery Rate of Prunus africana (Rosaceae) in South-West, Cameroon
}

\author{
MOMO SOLEFACK Marie Caroline ${ }^{1 *}$, NGUETSOP Victor François ${ }^{1}$, DONGMO NGUEMEWE \\ Josette $^{1}$, KENGUEM KINJOUO Ghislain' ${ }^{1}$ and AVANA-TIENTCHEU Marie Louise ${ }^{2}$
}

${ }^{1}$ University of Dschang, Faculty of Science, Department of Plant Biology, Laboratory of Applied Botany P.O. Box: 67, Dschang, Cameroon

${ }^{2}$ University of Dschang, FASA, Department of Forestry, P.O. Box: 222 Dschang, Cameroon

*Corresponding author.

\begin{abstract}
A bstract
Prunus africana is important for its bark used in the treatment of benign prostate hyperplasia in SouthWest Cameroon which has led to overexploitation of natural population of the species. Prunus africana is listed as an endangered species. Despite the relevance of bark, little information on the effects of some ecological and anthropic factors on the survival and bark recovery rate of Prunus africana is known. Debarking followed a combination of four factors: season of bark harvesting, three stem diameter classes and three intensities of trunk circumference debarked. After debarking, trees were trimestrially monitored for a two years period during which the survival of the tree and the speed of regeneration of the bark were recorded. Results show a dead rate of $13.33 \%$. The rate of recovery of the bark at low altitude was about $21.27 \mathrm{~cm} /$ year. The best season for debarking was the rainy season $(27.49 \mathrm{~cm} /$ year). Trees with a weak diameter $(20-30 \mathrm{~cm})$ showed a low rate of recovery $(18.28 \mathrm{~cm} /$ year $)$ and also those whose bark were peeled on a surface of $75 \%$ of the tree's diameter $(29.09 \mathrm{~cm} /$ year $)$. These factors have important implications in drawing strategies for sustainable harvesting, management and conservation of this species.
\end{abstract}

\section{Introduction}

The African cherry, Prunus africana (Hook f.) Kalkman (Rosaceae) is a montane tree that has a wide distribution in Africa, occurring in montane regions of central and southern Africa and on the islands of Bioko, Sao-Tomé, and Grand Comore (Kalkman, 1965). It has a long history of traditional uses and is the source of a nontimber forest product that has reached the international trade (Stewart, 2003). In the 1960s, bark extracts were found to be effective in the treatment of benign prostatic hyperplasia (Bombardelli and Morazzoni, 1997), and bark harvests began in Cameroon in the 1970s. Prunus africana, locally known in Cameroon as Pygeum or Kirah, is an evergreen hardwood tree with dark-brown longitudinal fissured bark and simple, thick, leathery, oval, leaves with pointed ends. It grows at 700-3000 meters above sea level, up to a height of 40 meters. It has creamy white flowers and produces black fleshy fruits resembling a cherry when ripe, which are eaten and dispersed by monkeys, birds and squirrels. It is long lived - up to 100 years and is one of the about 13 critical species, patchily distributed, in the rainy high altitude montane mixed forest ecosystems in Cameroon (Hall et al., 2000). The majority of Pygeum populations are in the North West, South West and Adamaoua regions of 
Cameroon, where they have been extensively exploited for their bark since the 1980s. Internationally it is of medicinal economic value. Bark is exported dried, chipped or powdered to USA and Europe to produce an extract used to treat benign prostrate hyperplasia. The extract is also a raw material for the burgeoning health, bio-product, diet supplement and pharmaceutical industry (Cunningham, 1993).

Early studies on the effects of bark harvest showed that the harvest affected population structure, increased mortality and decreased fecundity (Cunningham and Mbenkum, 1993; Nkeng et al., 2010; Stewart, 2009). However, quantitative studies to examine specific life history parameters and possible sustainable harvesting practices were begun only recently. Recent work has focused on domestication techniques, genetic variation among populations (Avana, 2006; Muchugi et al., 2006), and population inventories (Ingram and Nsawir, 2007). There is little information concerning effects of some ecological and anthropic factors on the survival and bark recovery rate of Prunus africana in South-west, Cameroon. This study is conducted to contribute to the evaluation of the effects of some ecological and anthropic factors on the survival and bark recovery rate of Prunus africana (Rosaceae) in South-west, Cameroon.

\section{Materials and methods}

\section{Study area}

The Mt. Cameroon area has been the most intensively studied area since 1992, reflected in the five inventories and studies conducted. Mount Cameroon is an active volcanic mount with $45 \mathrm{~km}$ long and $30 \mathrm{~km}$ wide, on a SW - NE axis on the coast of the Bight of Biafra, situated $3^{\circ} 57^{\prime}$ and $3^{\circ} 47^{\prime}$ North and $8^{\circ} 58^{\prime}$ and $9^{\circ} 24^{\prime}$ East. Situated in the South-West region of Cameroon, it is the highest peak in West and Central Africa, culminating at $4097 \mathrm{~m}$ above sea level. It is the only place in Africa where forest extends unbroken from sea level up to the tree line at $2500 \mathrm{~m}$ altitude. Its slopes are covered with lowland evergreen forest, sub-montane and montane forest, montane shrub and high altitude grassland all of which are characterized by a high level of plant endemism, with 45 endemic plants occurring only in the Mount Cameroon area (Cable and Cheek, 1998) and an equally rich wildlife. Maximum temperatures in the Mount Cameroon zone are attained in January and February, reaching an average of $30^{\circ} \mathrm{C}$, with minimum temperatures occurring in March and April at an average of $15^{\circ} \mathrm{C}$. The rainy season extends from April to September with the rainiest months in July and August, while January is generally dry. This area has well drained, porous Volcanic soils with rich organic top layers forming a type of Andosol.

\section{Species description}

Prunus africana is a canopy tree $30-40 \mathrm{~m}$ in height. Large-diameter trees have impressive, spreading crowns. Because of deforestation at lower elevations, it is confined to disjoint, genetically dissimilar populations (Avana, 2006; Muchugi et al., 2006). It is most abundant in open forest areas and disturbed habitats (Ewusi et al., 1992; Fashing, 2004). Tsingalia (1989) observed seedlings along forest margins where he suggested predation rates were lower, while Ndam (1998) found most seedlings in fallow fields or forest gaps. Thus, Prunus africana appears to be a light-demanding, secondary forest species. In the Kilum-Ijim Forest, Prunus africana has a clumped distribution (Ewusi et al., 1992). It is found as single individuals or in small stands, which may reflect its light demanding tendency or, may reflect past harvesting practices.

\section{Experimental design}

Debarking was conducted on two sites. For this species only healthy trees (no previous bark harvesting) were selected for the experiment. On each individual, bark was harvested from trunk at $1.30 \mathrm{~m}$ stem height. The wound was rectangular in shape with the vertical side 30 $\mathrm{cm}$ long and the horizontal width varying depending on the applied intensity. To assess the effect of harvesting seasons, trees of this species were harvested both during the dry and rainy seasons. We defined three classes of diameter at breast height (d.b.h.) at which debarking occurred: $20-30 \mathrm{~cm}, 31-40 \mathrm{~cm}$ and $>40 \mathrm{~cm}$. three intensities (I) of bark harvesting were implemented to cover the different harvesting practices (expressed in percentage of the circumference of the debarked tree): 25 $\%$ (I1), $50 \%$ (I2) and $75 \%$ (I3). We marked each selected trees with red paint. Bark was harvested from a total of 30 trees (Delvaux et al., 2010).

\section{Field measurements}

After bark harvesting, a quarterly follow-up for eighteen months for the individuals of the dry season and fifteen months for the individuals of the rainy season was carried out. For each tree its survival and extent of bark re-growth were recorded. A tree was considered dead 
when it lost all its foliage. Bark re-growth was considered as the development of tissues from the edge of the wound. This re-growth is called edge growth. Three horizontal measurements $(\mathrm{cm})$ were made from fixed points drawn on both sides (left and right) of the wound. To calculate the total edge growth $(\mathrm{cm})$, the mean values of these three measurements were added for both sides (left and right).

\section{Data analysis}

The results of the rate of covering and anatomical measurements obtained were subjected to a statistical analysis. The analysis of variance (ANOVA) was used to calculate the averages and the standard deviations. The test of Bonferroni was used to separate the averages when there was a significant difference $(\alpha=5 \%)$ and the software Graphpad InStat, 2000 was used statistical tool.

\section{Results}

\section{Effect of bark harvesting on the survival of the species}

At the beginning of this research, a total of 30 trees were debarked. During the period of study, 4 of the 30 trees debarked died. Regardless of seasons and treatments applied, mortality rates varied significantly in this species (Fig. 1). The mortality rate of harvested trees was higher when harvesting occurred in the dry season (15\%) than in the rainy season (5\%) (Fig. 1A).

Regarding the size of tree, the mortality rate remained high in the first class $[20-30 \mathrm{~cm}]$ in which there were 2 dead out of seven individuals debarked (28.57\%), followed by the second class $[31-40 \mathrm{~cm}]$ with one dead debarked on five individuals $(20 \%)$. The remained was weak in the last class [> $40 \mathrm{~cm}]$ with about $5 \%$, or a death in eighteen individuals debarked (Fig. 1B).

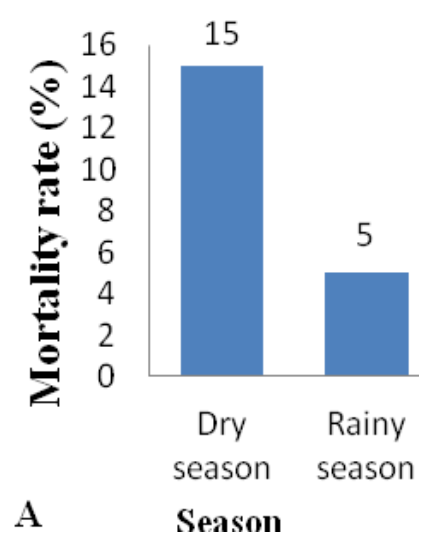

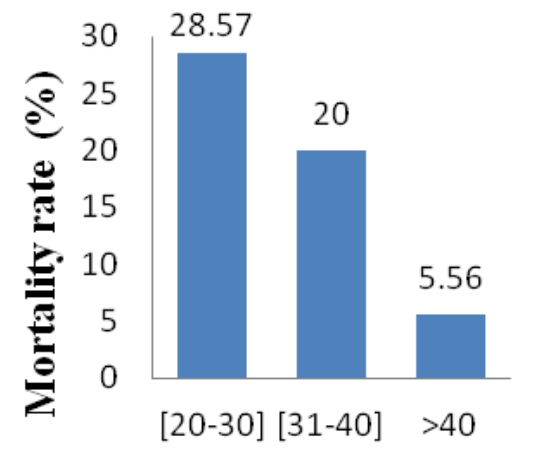

B
Diameter at breast height (cm)

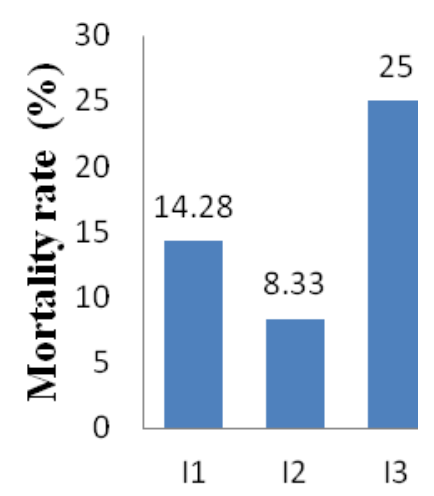

C Intensity of debarking

Fig. 1: Mortality rate (\%) after bark harvesting regardless of season (A), diameter (B) and intensity of bark harvesting inflicted (C).

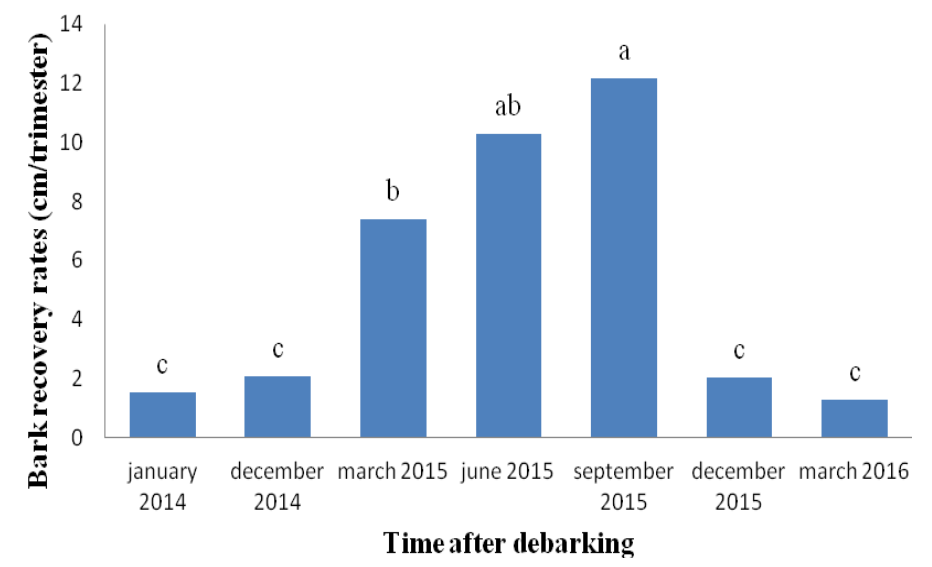

Fig. 2: Evolution of the bark recovery rate of the individuals of Prunus africana debarked in the rainy season.

\section{Bark recovery rates after debarking: Evolution of the bark recovery rate}

A total of ten (10) individuals were debarked in the rainy season. Fig. 2 shows the evaluation of the bark recovery rate of Prunus africana individuals in the rainy season. It is generally seen that the bark recovery rate is significantly high during the rainy months than during the dry months. Similarly, the quarterly average of the bark recovery rate of these individuals in the rainy season shows that the regeneration of the bark begins immediately at the first month even if it starts slowly $(1.53 \mathrm{~cm})$, it becomes significant after nine months $(7.39 \mathrm{~cm})$.

A total of 20 individuals were debarked in the dry season. Fig. 3 shows the evolution of the bark recovery 
rate of Prunus africana individual's debarked in the dry season. It appears that after debarking trees in the dry season, the debarked area is enlarged only after three months the bark starts to regenerate. Similarly, there is a significant bark recovery rate in June and September 2015.

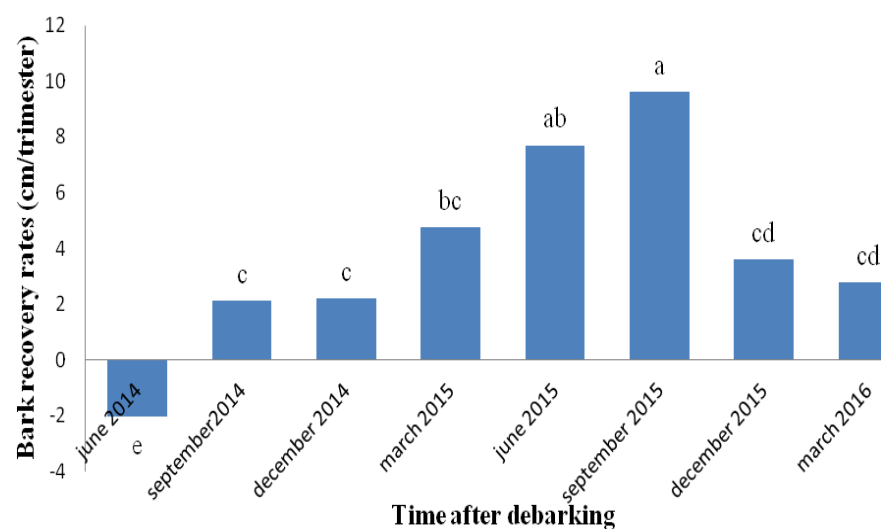

Fig. 3: Evolution of the bark recovery rate of the individuals of Prunus africana debarked in the dry season.

\section{Influence of altitude, season, dbh and intensity of harvesting on bark recovery}

The bark recovery rate between 2232 and $2284 \mathrm{~m}$ altitude is significantly higher than that of $900 \mathrm{~m}$ (Table 1).

Table 1. Influence of altitude, season, size class (dbh) and intensity of debarking of Prunus africana (mean \pm SE, $\mathrm{cm} /$ year) during the 2 years following bark harvesting. For each parameter, means followed by the same letters are significantly comparable at $p<0.05$.

\begin{tabular}{lll}
\hline Parameters & N & Mean \pm SE \\
\hline $\begin{array}{l}\text { Altitudes } \\
900 \mathrm{~m}\end{array}$ & 5 & $19.31 \pm 2.4 \mathrm{~b}$ \\
2232 to $2284 \mathrm{~m}$ & 25 & $21.27 \pm 1.21 \mathrm{a}$ \\
Seasons & & \\
Dry & & $17.52 \pm 7.94 \mathrm{~b}$ \\
Rainy & 20 & $27.47 \pm 8.21 \mathrm{a}$ \\
Size class (cm) & 10 & \\
{$[20-30]$} & 6 & $13.17 \pm 5.54 \mathrm{~b}$ \\
{$[31-40]$} & 5 & $22.2 \pm 7.41 \mathrm{a}$ \\
$>40$ & 15 & $22.4 \pm 4.55 \mathrm{a}$ \\
Intensity & & \\
$\mathrm{I}_{1}$ & 10 & $18.28 \pm 2.34 \mathrm{c}$ \\
$\mathrm{I}_{2}$ & 9 & $22.51 \pm 3.07 \mathrm{ab}$ \\
$\mathrm{I}_{3}$ & 7 & $29.09 \pm 5.86 \mathrm{a}$ \\
\hline
\end{tabular}

The debarking season affects the bark regeneration of Prunus africana. This regeneration is more significant ( $\mathrm{P}$ $<0.05)$ in the rainy season $(27.47 \mathrm{~cm} /$ year $)$ than in the dry season $(17.52 \mathrm{~cm} /$ year). It is interesting to note that the size of the tree have an effect on the bark recovery rate for Prunus africana. Regeneration of its bark is significantly $(p<0.05)$ higher in classes containing medium and large diameters (Table 1). The bark recovery rate of Prunus africana also depends on the debarked surface area. Individuals whose bark was taken from $75 \%$ area (I3) of the trunk has a bark recovery rate of $24.09 \mathrm{~cm} /$ year which is significantly $(p<0.05)$ higher than those of individuals whose bark was taken from a $25 \%$ area $(18.28 \mathrm{~cm} /$ year $)$. The present study results highlights that the larger the debarked surface area the higher the amount of bark produced per year.

\section{Discussion}

\section{Effect of bark harvesting on the survival of the species}

Our study showed that the season of bark harvesting was found to influence the survival of Prunus africana. The trees treated in dry season suffered significantly higher mortality rate than those treated in the rainy season and wider strip width had a significant negative effect. Diameter and intensity were found to affect the survival of Prunus africana. However, higher diameter trees ( $>40$ $\mathrm{cm}$ ) of this species showed significantly higher mortality compared to smaller trees $(20-30 \mathrm{~cm})$. The mortality rate of trees that were debarked at $75 \%$ of their trunk circumference was higher compared to the others.

There are several ecological studies that have suggested that certain harvesting intensities and methods impact on survival, reproduction of target species. For example, inappropriate bark harvesting methods such as ring barking of trees resulted in mortality of all trees of Khaya senegalensis (Gaoue and Ticktin, 2007), Garcinia lucida in Cameroon (Guedje et al., 2007), and Lannea kerstingii, Maranthes polyandra, Parkia biglobosa, Pseudocedrela kotschyi in Benin (Delvaux, 2009). The exact cause of death in a particular tree cannot be known, although harvested Prunus africana trees are known to be attacked by insects or fungal diseases, and trees can become dehydrated if the tree was harvested in the dry season (Geldenhuys et al., 2007).

A species may survive ring-barking, if it is able to recover the bark rapidly by producing a surface callus from the wound callus. The surface callus originates from the trunk cambium and/or from dedifferentiation of immature xylem cells (Stobbe et al., 2002). 
Bark recovery rates after debarking, influence of altitude, season, dbh and intensity of harvesting on bark recovery

The results of this study showed that the bark recovery of Prunus africana is influenced by several factors: season and intensity of debarking, size of tree and altitude. Our results illustrate that bark harvesting during the rainy season led to a better bark recovery in Prunus africana. The humidity of the exposed wound is the most important factor allowing the start of the bark recovery process (Stobbe et al., 2002; Mwange et al., 2003). Therefore, the physiological status of trees, in terms of upward or downward sap flow due to water supply, as it plays an important role in maintaining bark functioning, appears as a decisive factor in plant survival and bark regrowth process; thereby constituting a key element in designing sustainable harvesting practice. Several studies have shown that another important factor for successful recovery of bark was the humidity of the exposed surface immediately after wounding, which may be related to the occurrence of a rainy season (Juan et al., 2006).

It is interesting to note that the size of the tree have an effect on the bark recovery rate for Prunus africana, but the size class of trees showing the low bark recovery was 20-30 cm. This confirmed observations obtained by Guedje et al. (2007) in Cameroun and study of Vermeulen et al. (2012) who recorded good bark regrowth in bigger diameter trees on the same trees after 36 months. This is an important finding given that inventories conducted in Kwazulu-Natal (Geldenhuys 2004) and in Cameroon (Guedje et al., 2007) indicated that bark harvesters avoid smaller trees and target bigger trees that have better vitality and good bark recovery, which might consequently mitigate the impact of bark harvesting on the species. However, if the demand for bark of a certain species is very high, as for example in the case of Prunus africana in Cameroon, Madagascar and Island of Bioko, all sizes were found to be barkharvested (Cunningham and Mbenkum 1993; Stewart, 2003).

The bark recovery rate is proportional to debarked surface area. Indeed, the more the debarked surface area is large, the more its recovery rate is higher per year. This could be explained by a higher hormonal activity stimulated by stress in order to restore water conductivity and thus to close the wound as soon as possible. The most probable hormones to be released are auxins and cytokinines, both being involved in cell division and shoot formation (Mohr and Schopfer, 1995). Moreover their highly-synergistic effect affects most of the growth processes of plants.

Cunningham and Mbenkum (1993) indicated that Prunus africana in Cameroon can achieved complete bark re-growth after ring barking. Bark regrowth from the edges recorded for Prunus africana trees was also found for Drimys brasiliensis (Mariot et al., 2014) and Himatanthus drasticus (Baldauf and dos Santos, 2014). However, over the two-year follow-up period, some trees are able to close the wound completely, suggesting a recovery time of about two years. Delvaux et al. (2010) found that only four species, out of the 12 they studied, showed a good recovery rate and that only Khaya senegalensis and Lannea kerstingii were able to close the wound completely over the two-year follow-up period.

\section{Conclusion}

At the end of our study which was to assess the influence of the seasons debarking, size of tree, the intensity of debarking and altitude on the survival and bark recovery rate of Prunus africana in Mount Cameroon, it appears that the survival and regeneration of the bark of this species is based on these above- mentioned parameters. Indeed, we have noted throughout a high mortality rate in the dry season as well as in individuals with a diameter between 20 and $30 \mathrm{~cm}$ and ones whose bark was removed over an area of $75 \%$ (I3).

The regeneration of the bark is suitable in the rainy season compared to the dry season. When debarking Prunus africana in a large area (I3) and trees with diameters between 31 and $40 \mathrm{~cm}$, the tree quickly overcomes the trauma and develops new tissue to survive. These factors have important implications in drawing strategies for sustainable harvesting, management and conservation of this species.

\section{Conflict of interest statement}

Authors declare that they have no conflict of interest.

\section{Acknowledgement}

The authors are grateful to the International Foundation of Science (IFS) for providing grant for this project titled «Descriptive anatomy of bark regeneration of some economically interesting plants in Cameroon», grant number D/5471-1. 


\section{References}

Avana, M.L., 2006. Domestication de Prunus africana: Etude de la germination et du bouturage Thèse du Doctorat/PhD, Université de Yaoundé 1. 160p.

Baldauf, C., Maës, d.S.FA., 2014. The effect of management systems and ecosystem types on bark regeneration in Himatanthus drasticus (Apocynaceae): recommendations for sustainable harvesting. Environ. Monit. Assess. 186(1), 349-359.

Bombardelli, E., Morazzoni, P., 1997. Prunus africana Hook.f. Kalkman. Fitoterapia. 68(3), 205-218.

Cable, S., Cheek, M., 1998. The Plants of Mt. Cameroon: a Conservation Checklist. Royal Botanical Gardens, Kew.

Cunningham, A.B., 1993. African Medicinal Plants: Setting Priorities at the Interface Between Conservation and Primary Healthcare. People and Plants working paper 1. Paris, UNESCO.

Cunningham, A.B., Mbenkum, F.T., 1993. Sustainability of harvesting Prunus africana bark in Cameroon: A medicinal plant in international trade. People and Plant Initiative Working paper 2. UNESCO, $28 \mathrm{p}$.

Delvaux, C., 2009. "Strip-trees": the life after. Responses to bark harvesting of medicinal tree species from Forêt Classèe des Monts Kouffe, Benin. PhD thesis, Ghent University, Belgium. 155 p.

Delvaux, C., Sinsin, B., Van Damme, P., Beeckman, H. 2010. Wound reaction after bark harvesting: microscopic and macroscopic phenomena in 10 medicinal tree species (Benin). Trees-Struct. Funct. 24, 941-951.

Ewusi, B. N., Tanyi C.T, Nyambi, J., Acworth, J., 1996. Bark extraction: current situation and sustainable cropping of Prunus africana on Mount Cameroon. Mount Cameroon Project, Limbe, Cameroon.

Fashing, P., 2004. Mortality trends in the African cherry (Prunus africana) and the implications for colobus monkeys (Colobus guereza) in Kakamega Forest, Kenya. Biol. Conserv. 120, 449-459.

Gaoue, O.G., Ticktin, T., 2007. Patterns of harvesting foliage and bark from the multipurpose tree Khaya senegalensis in Benin: Variation across ecological regions and its impacts on population structure. Biol. Conserv. 137(3), 424-436.

Geldenhuys, C.J., 2004. Bark harvesting for traditional medicine: From illegal resource degradation to participatory management. Scand. J. Forest Res. 19, 103-115.

Geldenhuys, C.J., Syampungani, S., Meke, G.S., Vermeulen, W.J., 2007. Response of different species to bark harvesting for traditional medicine in Southern Africa. In Multiple Use Management of Natural
Forests and Woodlands: Policy Refinement and Scientific Progress. pp.55-62.

Guedje, N.M., Zuidema, P.A., During, H., Foahom, B., Lejoly, J., 2007. Tree bark as a non-timber forest product: The effect of bark collection on population structure and dynamics of Garcinia lucida Vesque. Forest Ecol. Manag. 240(1-3), 1-12.

Hall J., O’Brien, E., Sinclair, F., 2000. Prunus africana, A Monograph. University of Wales Bangor, Mount Cameroon Project, IRCRAF. Sciences, S. o. A. F. Publication No 18, University of Wales Bangor, School of Agricultural and Forest Sciences. 104p.

Ingram, V., Nsawir, A.T., 2007. The value of biodiversity, Pygeum: Money growing on trees in the Cameroon highlands. Nat. Faune. 22(1), 29-36.

Juan, D., Hong-Li, X., De-Qiang, Z., Xin-Qiang, H., MinJie, W., Ying-Zhang, L., Ke-Ming, C., Meng-Zhu, L., 2006. Regeneration of the secondary vascular system in poplar as a novel system to investigate gene expression by a proteomic approach. Proteomics. 6(3), 881-895.

Kalkman, C., 1965. The old World species of Prunus subgenus Laurocerasus. Blumea. 10, 1-174.

Mariot, A., Mantovani, A., Reis, M.S., 2014. Bark harvesting systems of Drimys brasiliensis Miers in the Brazilian Atlantic rainforest. An. Acad. Bras. Cienc. 86(3), 1315-1326.

Mohr, H., Schopfer, P., 1995. Plant Physiology. SpringerVerlag, Berlin, Heidelberg, New York.

Muchugi, A., Lengkeek, A.G., Kadu, C.A.C., Muluvi, G.M., Njagi, E.N.M., Dawson, I.K., 2006. Genetic variation in the threatened medicinal tree Prunus africana in Cameroon and Kenya: Implications for current management and evolutionary history. South Afr. J. Bot. 72, 498-506.

Mwange, K.N., Hou, H.W., Cui, K.M., 2003. Relationship between endogenous indole-3-acetic acid and abscisic acid changes and bark recovery in Eucommia ulmoides Oliv. after girdling. J. Exp. Bot. 54(389), 1899-1907.

Ndam, N., 1998. Tree regeneration, vegetation dynamics and the maintenance of biodiversity on Mount Cameroon: the relative impact of natural and human disturbance. Ph.D. thesis, University of Wales Bangor. 278p.

Nkeng, P.F., Ingram, V., Awono, A., 2010. Assessment of Prunus africana bark exploitation methods and sustainable exploitation in the South west, North-West and Adamaoua regions of Cameroon. CIFOR (Center for International Forestery Research) Report. pp.1-55.

Stewart, K., 2009. Effects of bark harvest and other human activity on populations of the African cherry (Prunus africana) on Mount Oku, Cameroon. Forest Ecol. Manag. 258, 1121-1128. 
Stewart, K.M., 2003. The African cherry (Prunus africana): Can lessons be learned from an overexploited medicinal tree? J. Ethnopharmacol. 89, 313.

Stobbe, H., Schmitt, U., Eckstein, D., Dujesiefken, D., 2002. Developmental stages and fine structure of surface callus formed after debarking of living lime trees (Tilia sp.). Ann. Bot. 89(6), 773-782.
Tsingalia, M.H., 1989. Variation in seedling predation and herbivory in Prunus africana in the Kakamega Forest, Kenya. Afr. J. Ecol. 27, 207-217.

Vermeulen, W.J., Geldenhuys, C.J., Esler, K.J., 2012. Response of Ocotea bullata, Curtisia dentata and Rapanea melanophloeos to medicinal bark stripping in the Southern Cape, South Africa: Implications for sustainable use. Southern Forests. 74(3), 183-193.

\section{How to cite this article:}

Momo Solefack, M. C., Nguetsop, V. F., Dongmo Nguemewe, J., Kenguem Kinjouo, G., And Avana-Tientcheu, M. L., 2016. The effects of some ecological and anthropic factors on the survival and bark recovery rate of Prunus africana (Rosaceae) in South-West, Cameroon. Int. J. Curr. Res. Biosci. Plant Biol. 3(8), 25-31. doi: http://dx.doi.org/10.20546/ijcrbp.2016.308.004 